Journal of Jungian Scholarly Studies

Vol. 4, No. 2, 2008

\title{
Shadow Dynamics in Aphra Behn's Oroonoko
}

Matthew A. Fike, Ph.D.

Winthrop University

Jung writes in "Psychology and Literature" (1930) "that the manifestations of the collective unconscious [in literature] are compensatory to the conscious attitude, so that they have the effect of bringing a one-sided, unadapted, or dangerous state of consciousness back into equilibrium" ( $C W 15,152)$. This compensatory feature of literature is present in Aphra Behn's Oroonoko, for the novel reflects and critiques the psychological disequilibrium that fosters slavery. Rather than being properly integrated, the shadow of various male characters, mainly William Byam, is projected onto Oroonoko and manifests as extreme brutality, while the anima is projected onto women, mainly Imoinda and the narrator. These twin projections are complementary. The male psyche attributes fault to (and brutalizes) a male Other partly because it wrongly attributes virtue and the feminine to various female Others, rather than genuinely fostering those qualities in itself. Behn links these two projection processes in important passages where the worst actions are perpetrated in the absence of women, as though women, if they were present, would have a tempering influence. The novel thus enacts the essentialist fallacy that characterizes C. G. Jung's attribution of gender to biological sex over three centuries later. Using the tools of feminist deconstruction, this essay seeks to critique Behn's use of essentialism in Oroonoko in order to understand the tragic impulse that results when anima and shadow are projected rather than integrated.

Oroonoko tells the story of Prince Oroonoko of Coramantien on the Gold Coast of Africa in present-day Ghana-a successful general who falls in love with the beautiful Imoinda. Their romance, however, is foiled by his jealous grandfather, the impotent King, who takes the young woman as his own wife. After the young lovers disobey him by consummating their relationship, the King has her sold into slavery, though Oroonoko believes that she has been executed. After the King welcomes him back into the fold, Oroonoko is tricked by an English captain into visiting a slave ship and is whisked off to Surinam, the British colony in Guiana, where he is sold to a man from Cornwall named Trefry, on whose plantation Oroonoko is improbably reunited with Imoinda. They are renamed Caesar and Clemene. They marry, and she becomes pregnant. Impatient to achieve the freedom 
that he has been promised so that their child will not be born into slavery, Oroonoko leads a mass exodus of slaves, is captured and tortured, recovers, and kills Imoinda while plotting violent revenge that he never actually achieves because of his grief and self-mutilation. He is brutally dismembered in the novel's final scene.

Jung's few comments on slavery in the Collected Works deal with it in a classical rather than an African or a New World context, but his comments on European experience are relevant and helpful in an approach to Oroonoko. A statement in his essay "Crime and the Soul" (1932) exactly describes the psychic compartmentalization that takes place in the novel. He writes: "A very large number of criminals lead a thoroughly middle-class existence and commit their crimes, as it were, through their second selves. Few criminals succeed in attaining a complete severance between their liking for middle-class respectability, on the one hand, and their instinct for crime on the other" ( $C W$ 18, 800). This remark characterizes some of the whites in Behn's novel, especially slave owners and managers who, the narrator tells us, "consisted of such notorious villains as Newgate never transported, and possibly originally were such, who understood neither the laws of God or man, and had no sort of principles to make them worthy the name of men" (69; see Ferguson 48). Of course, the novel's most notorious noncriminal is William Byam, Surinam's lieutenant governor, whose brutality masquerades as legal authority. He is what Jung in "On the Psychology of the Trickster-Figure" (1956) calls the "so-called civilized man...[who] never suspects that his own hidden and apparently harmless shadow has qualities whose dangerousness exceeds his wildest dreams. As soon as people get together in masses and submerge the individual, the shadow is mobilized, and, as history shows, may even be personified and incarnated" ( $C W 9 \mathrm{i}, 478)$. Institutional slavery is such an aggregate, and Byam is its statutory personification.

Jung's further insights do not square precisely with Behn's depictions, but shadow projection is an essential concept for understanding Oroonoko. Jung is especially critical of how "National Socialism" "splits off the conscious from the unconscious man more and more menacingly" ( $C W$ 9i, 453; $C W 10,559)$. Like Communism, it "threatens our freedom with tyranny and slavery"; "the State became all-powerful and claimed its slaves body and soul" (CW 10, 818; $C W 18$, 1324; my emphases). In short, although Jung does not address modern slavery directly, he does describe life in a repressive regime as slavery. Like the political systems that Jung mentions, a state that tolerates slavery provides a context for male shadow projection to manifest as brutality. For Behn, collectivity does mobilize the shadow under the guise of state authority; however, the target is not the state's own citizens but the Other in remote locations like Africa and Surinam. As in Conrad's Heart of Darkness, Europe's shadow is largely displaced onto a primitive landscape where the nonintegrated shadow is indeed "personified and 


\section{Fike}

incarnated." As Rinda West observes in her chapter on Heart of Darkness, "The imperial conquerors' image of themselves as the great civilizers required that they deny their own brutal impulses. They projected these dangerous qualities onto those they were brutalizing, casting Africans and Indians, along with their land, as 'savage'..." (35-36). Instead of doing inner work, the whites, who are driven by the profit motive, project their negativity onto Oroonoko and punish him for it. And the more unconscious one is, the more powerful the projection becomes. As Jung puts it, "Everyone carries a shadow, and the less it is embodied in the individual's conscious life, the blacker and denser it is" $(C W 11,131)$. There is no "blacker and denser" object of projection in the novel than Oroonoko himself, whose blackness, the narrator says, is "not of that brown, rusty black which most of that nation are, but a perfect ebony or polished jet" (15). Together the two statements suggest that the blackest of slaves is a likely target for most brutal kind of male shadow projection.

Rather than dealing directly with shadow projection, however, the criticism written to date has focused on such issues as the novel's historical, biographical, narrative, and feminist underpinnings, none of which falls naturally within a Jungian rubric. Nevertheless, various critics do notice that violence is perpetrated in the absence of women; but far from noting that a dysfunctional relationship to anima allows the nonintegrated male shadow to lapse into brutality, their statements echo the novel's essentialism. Robert L. Chibka states, "Thanks to her [the narrator's] absence, Oroonoko is dreadfully whipped, and she is absent because she did not trust his promise [not to harm anyone]" (523). Moira Ferguson notes that Behn "twice has the narrator abandon her friend at critical junctures. ... In the narrator's absence, he [Oronooko] is mauled [by whipping] the first time and killed the second" $(28,38)$. Ferguson continues: "Despite being Oroonoko's companion who formerly diverted him from thoughts of escape, she fails twice to support him when he is in extremis. She withdrew and may, in her own eyes, have forsaken her friend" (48). Stephanie Athey and Daniel Cooper Alarcón state: "The narrator deftly attributes these departures to threats or sentiments that seem to affect white females exclusively. ... The white female body alone has fled the scene, effectively removing itself from the scene of colonial struggle and leaving the white male to personify colonial power" (38-39). Jane Spencer notes that the narrator is indeed absent at "key moments" (192). And Jacqueline Pearson says this about the narrator: "She feels she has 'Authority', and yet she is absent on the two crucial occasions when that authority could have been used, when Oroonoko is whipped and when he is executed" (135). In other words, various critics notice that brutality spikes in the absence of females, but critics are more interested in what this pattern augurs for the absent narrator's complicity with colonial authority than 
in the psychology of the male victim and his victimizers. As the novel eventually bears out, whether present or absent, the narrator is unlikely to prevent brutality because a man's anima is not the woman on whom he projects it. A female character's absence symbolizes men's lack of anima integration and highlights the need for the anima, not an external woman, to temper a man's actions. The point is not that the narrator, however well-intentioned, could change the outcome if she were present but that change must arise from greater integration within the male psyche.

The essentialism that subtly underlies these critical statements about the novel is encapsulated in a couplet from the poem "Virtue and Charm" by medieval German poet Walter Von Der Vogelweide: "He who good woman's love doth heed / Will blush to do an evil deed" (32). A good woman's presence, the poet believes, discourages a man from doing bad deeds perhaps because anima projection momentarily quells shadow behavior (that is, such projection of the anima keeps shadow projection at bay). The couplet's further implication — and Jung's, as Susan Rowland observes - is a gender bifurcation in which Logos/reason is the province of men, whereas women are embodiments of Eros/relatedness (C. G. Jung and Literary Theory 14). As Rowland sums up the problem, "Jungian writings generalise from the fascinating and hypnotic anima image in the masculine unconscious to indict all women in a masquerade of femininity. Women become animas in Jungian theory[,] a theory thereby made hysterical in its inability to be coherent about the feminine" (Literary Theory 191). Rowland attributes this gender essentialism to Jung's use "of his own unconscious anima" in the formulation of his theory (Jung: A Feminist Revision 19). Yet despite his tendency "to collapse gender into bodily sex," Rowland admits that "he cannot be described straightforwardly as a gender essentialist owing to the priority given to plurality and androgyny in the unconscious" (Feminist Revision 45).

Granted, Jung is an essentialist, albeit a qualified one; but so (ironically) is Behn's female narrator who seems to believe that her mere presence prevents the potential for male violence. It is this essentialism - as gender bifurcation and the attendant projection as opposed to psychic integration - that drives the novel toward tragedy. In other words, the flaws in Jungian theory, sans feminist revision, directly parallel and can helpfully illuminate the psychological forces that afflict the main characters. The essentialist comments of Robert Johnson, for example, sum up almost precisely the kind of shadow dynamics that Behn's novel enacts. The feminine, he states, relates to "qualities that bring meaning into life: relatedness to other human beings, the ability to soften power with love, awareness of our inner feelings and values, respect for our earthly environment, a delight in earth's beauty, and the introspective quest for inner wisdom" (19-20). But the masculine, Johnson adds, if it is isolated from the feminine, pursues "power, production, prestige, and 'accomplishment"; thinks "only of empire building, 


\section{Fike}

accumulation of territory and wealth, and domination of the environment at any cost"; and achieves power through brutality and destruction at the expense of "love, feeling, and human values" (21-23). Johnson further states:

No aspect of the human psyche can live in a healthy state unless it is balanced by its complementary opposite. If the masculine mind tries to live without its "other half," the feminine soul, then the masculine becomes unbalanced, sick, and finally monstrous. Power without love becomes brutality. . . . When one side of human nature grows out of balance with the other, it becomes a tyranny in the soul. (23; Johnson's emphasis)

The words "monstrous" and "brutality," as we shall see, have particular resonance with Behn's Oroonoko, as does Johnson's comment on the sword image: without the feminine harp, the sword, which "symbolizes the sharp, aggressive wielding of masculine power...is reduced to egotistical brute force" (29-30); the sword may even, as I will argue, be turned against the projection of a man's own feminine side. As with Jung, so with Johnson: the bifurcation of masculine and feminine is a flawed theory; but a man's psyche, in order to be healthy, must consciously integrate masculinity and femininity into the wholeness of the Self. That much is true; and Johnson's prescription-because of its essentialist flaws-is a helpful lens for viewing a novel that subscribes to the same fallacy. On the surface, Behn's portrayal of male brutality in the absence of females supports the essentialist notion that, for males, the nonintegrated shadow becomes brutality without a mitigating female presence. The absent feminine, however, is significant not in itself but as a symbolic image of the male psyche: the landscape of characters is actually an inscape of archetypes.

We begin with a troubling passage that illustrates the close relationship between essentialism and projection by depicting Oroonoko's unawareness that he is projecting his own anima and shadow. The narrator says the following about Imoinda's effect on Oroonoko's psyche: “...the awfulness [awe] wherewith she received him, and the sweetness of her words and behavior while he stayed, gained perfect conquest over his fierce heart. So that having made his first compliments and presented her a hundred and fifty slaves in fetters, he told her with his eyes, that he was not insensible of her charms..." (16). Like Behn and her narrator, neither Oroonoko nor Imoinda opposes slavery per se; they are merely opposed to the enslavement of upper-class persons, especially royalty. For them, there is no contradiction: Oroonoko can heed a good woman's love and still enslave lowerclass Africans because the latter act is not considered an evil deed. At a minimum, his ironic complicity in the slavery that he later suffers suggests a morally relative ground where relationship with a woman and injustice to others can coexist. On the 
cultural level, the hero himself participates in an established institution: slavery is customary in Africa, much as it is legal in the new world. In Africa, enslaving others (an evil deed) and enjoying a woman's love are not in binary opposition; one furthers the other and lends dramatic logic to Oroonoko's own enslavement. He reaps what he sows. In psychological terms, however, enslaving others and loving Imoinda are complementary acts of projection, of shadow and anima, respectively. Locating the feminine in Imoinda takes the place of realizing and integrating the anima within himself, and shadow projection (enslaving others) appears as an unconscious byproduct. In other words, anima projection stands in for anima integration, and Oroonoko treats his fellow Africans as Other in much the same way that his white enslavers will regard him.

The essentialism and anima projection continue in the new world when Imoinda has an even more salutary effect on men, both whites and blacks, as though "[h]er power saps men's strength, rendering the most eminent submissive in her presence" (Sussman 121). In the first half of the novel, the narrator's comment anticipates Imoinda's effect on the men in Surinam: "I have seen an hundred white men sighing after her and making a thousand vows at her feet, all vain and unsuccessful" (16). Later Trefry notes "that all the white beauties he had seen, never charmed him so absolutely as this fine creature had done; and that no man of any nation ever beheld her that did not fall in love with her, and that she had all the slaves perpetually at her feet, and the whole country resounded with the fame of Clemene" (45). Focused on Imoinda, the slaves are unlikely to revolt; only Oroonoko's masculine agency foments a rebellion later in the narrative. For now, the lovers experience "joy and pleasure" in each other's presence so that "even fetters and slavery were soft and easy" (47). In love with a good woman, Oroonoko does not yet have rebellion on his mind; Imoinda's love enables toleration of an evil institution. The feminine prevents masculine brutality in Trefry's case as well: he has contemplated raping her but notes that "she disarms me with that modesty and weeping so tender and so moving that I retire, and thank my stars she overcame me" (46; Behn's emphasis). Quotations such as these indicate that characters fail to distinguish between their own inner feminine principle and outer women. The anima is projected rather than being properly integrated, though this process for the present forestalls shadow projection.

Like the teenaged Imoinda, the narrator (not many years her senior) has a similar, though not sexualized, effect on Oroonoko. She describes how she "was obliged...to discourse with Caesar when he becomes more impatient for the promised liberty. She "entertained him with the lives of the Romans" and with Christian theology-discussions that distract him from his concerns. In this episode, she is clearly complicit in his captivity because a female presence mollifies and, for the moment, defuses a potentially brutal masculine agent by gently informing him that he will be confined if he acts out (projects his shadow). 


\section{Fike}

He then admits what the reader already knows - that he has "suffered slavery so long" because of "love alone" (49); that is, he attributes his passivity-in-captivity to the tempering influence of his beloved Imoinda (49). From a Jungian standpoint, however, this admission is ominous because when the hero's psychic content is repressed rather than integrated, the shadow festers.

What is worse than projecting the anima onto a woman is to fight a symbolic image of it, which is what happens next. Since Oroonoko's spirit remains "rough and fierce" (50), he needs more action than the narrator's conversations can supply; so the Europeans engage him as their guide on various excursions into the jungle where he kills two tigers. The gender shifts in the narrator's description of the tiger slayings provide a key to the way in which these episodes further a point about shadow projection in the form of brutality. When the first beast comes at the party because they have been playing with its cub, Oroonoko

ran his sword quite through his breast, down to his very heart, home to the hilt of the sword. The dying beast stretched forth her paw, and going to grasp his thigh, surprised with death in that very moment, did him no other harm than fixing her long nails in his flesh very deep, feebly wounded him, but could not grasp the flesh to tear off any. (53; my emphasis)

Whereas this first tiger is male but becomes female in the killing, the second (a female) becomes male as it dies. Oroonoko

shot her just into the eye; and the arrow was sent with so good a will and so sure a hand that it struck in her brain and made her caper and become mad for a moment or two, but being seconded by another arrow, he fell dead upon the prey. Caesar cut him open with a knife, to see where those wounds were that had been reported to him, and why he did not die of them. ...but when the heart of this courageous animal was taken out, there were seven bullets of lead in it, and the wounds seamed up with great scars, and she lived with the bullets a great while, for it was long since they were shot. (54; my emphasis)

In one reading, the eye and heart body forth essentialism: eye/head/Logos/reason versus heart/Eros/relatedness/emotion. However, these images also relate to Jung's link between animals and the feminine. He writes, "The anima also has affinities with animals, which symbolize her characteristics. Thus she can appear as a snake or a tiger or a bird" $(C W 9 \mathrm{i}, 358)$. Eric Miller emphasizes the same point when he writes, "Pliny's tiger emphatically belongs to the female sex: the archetypal tiger is a 'she,' and a reproductive 'she' at that" (56-57). So the tigers, however their genders may shift, appear to figure forth the anima; and Johnson's view of the 
sword and the harp is relevant to Oroonoko's actions. Masculine images (the sword, the arrow) are not balanced with anything feminine; instead, they penetrate the feminine heart and eye (cf. Othello's reference to Desdemona's "precious eye" at 4.3.68). As Miller also notes, the word "eye," the ocular organ, is a pun on "I," the first-person pronoun, so that Oroonoko's attack on the tiger represents his own inner dysfunction (64). Thus the tiger episodes suggest not only that gender is bifurcated in the novel but also that the masculine is attacking and slaying the feminine, the death of which ultimately causes Oroonoko's psychic disintegration. That is, fighting the tigers enacts Oroonoko's unconsciousness of his own feminine aspect and his losing battle for inner wholeness.

There is yet a deeper dimension of the projection process in the tiger slayings. It is especially significant that Oroonoko's sword pierces the tiger's heart in the first case and that he removes the bullet-ridden heart of the second tiger, for both hearts anticipate his murder of Imoinda, on whom he projects his heart and soul. The tigers' hearts may be "the heart of female Nature," as Robert A. Erickson suggests (210), but they also represent Oroonoko's own heart-his emotional life and well-being. In Africa, their love talk has the following effect: "She [Imoinda] was touched with what he said, and returned it all in such answers as went to his very heart, with a pleasure unknown before" (17; my emphasis here and below). In Surinam, "Her griefs were so many darts in the great heart of Caesar" (61). And as the narrator notes after the trip on which the tigers are slain, "his heart...took part with his charming Imoinda" (70-71). He believes that she is not only his heart but also his soul, and the latter association reinforces her role as a projection of his anima/unconscious. As the narrator states,

they spoke so well and so effectually, as Imoinda no longer doubted but she was the only delight and the darling of that soul she found pleading in them its right of love, which none was more willing to resign than she. And it was this powerful language alone that in an instant conveyed all the thoughts of their souls to each other, that they both found there wanted but opportunity to make them both entirely happy. (23; my emphasis)

Even more directly, she is later called "this treasure of his soul" (71). Jung is quite clear that anima, meaning the "soul," often personifies the unconscious for all persons, particularly the collective unconscious ( $C W 9$ i, 57, 55; $C W 11,107$; and $C W 14,128)$. Simply put, Oroonoko's relationship with Imoinda does not connect with the unconscious and provide a context for inner work. Rather, he projects onto her his feminine principle and his feminine soul. For him, she becomes the keeper and embodiment of these qualities; he does not welcome them into the wholeness of the Self. When he destroys her, even anima projection ceases, and psychic integration is no longer possible: murdering his beloved represents the forcible disconnection with the anima. 


\section{Fike}

To sum up this section on the tigers, we have moved beyond a stage in the projection process where women are said to prevent brutality by keeping the nonintegrated male shadow in check, to a stage where the male hero brutally attacks wild animals who figure forth his own masculinity and femininity. Oroonoko's psyche is at war with itself, and shifting gender pronouns signal a lack of psychic integration: male, then female; female, then male; complementarity to be sure but never a healthy unity of both. The masculine attacks the feminine, and the feminine attacks back, sinking its claws into the hero, only to be permanently banished in the killing of Imoinda. The tiger slayings, then, insofar as they represent the unintegrated anima, foreshadow the disintegration of Oroonoko's psyche.

Following the tiger episodes, Oroonoko begins to realize that the white people's promises are hollow; and he organizes a slave rebellion, which fizzles in a way that illustrates the essentialist assumption that the presence of a woman obviates the need for inner work-that an outer complement stands in for genuine integration. The men are dissuaded from their course because they have wives and children (62). As Charlotte Sussman notes, "the sentimental attachments between husbands, wives, and children work to keep the slaves in captivity" (224). As with Oroonoko's love of Imoinda earlier in the book, women's love makes men forgo a good deed (in this case, resisting an evil institution). The hero is baited back into captivity by phony paperwork and is then brutally whipped, after which "Indian pepper" is rubbed into his wounds (67). This brutality is reported to the narrator because the fear that he would cut everyone's throats "made all the females of us fly down the river to be secured, and while we were away they [the men] acted this cruelty" (68). What she says next is crucially important: "For I suppose I had authority and interest enough there, had I suspected any such thing to have prevented it..." (68). The narrator believes that a feminine presence could curb the shadow and prevent male brutality if, in fear and complicity, the women had not fled. But the greater point is that the men's curbing of the shadow would be a repressive act that is not equivalent to integrating either shadow or anima. We are still in the realm of essentialism - women's presence may activate anima projection but not the opposing process of individuation.

The narrative then moves swiftly to Oroonoko's decapitation of the pregnant Imoinda or, in psychological terms, the ultimate disunity with his own feminine side; and the resulting psychic disintegration renders him unable to execute the desired revenge on his captors. Now "his grief swelled up to rage; he tore, he raved, he roared like some monster of the wood, calling on the loved name of Imoinda." The whites even say, "O monster! that hast murdered thy wife" (73; Behn's emphasis). The two statements may echo Shakespeare's phrase, "some monster in 
thy thought," a fairly clear locution of the shadow in Othello, a play about another wife-murderer (3.3.119). In Behn's novel, the shadow manifests in Oroonoko's vow "to finish the great work" of his revenge; but he only kills one man after ripping out his own entrails, which "recalls that he has just effectively aborted Imoinda's child" (Sussman 220). When he heals from his self-inflicted wound, the whites execute him. The narrator is absent on this occasion as well, as are the good white men (Colonel Martin and Trefry); she hears the details of Oroonoko's death from her mother and sister who, in an echo of the crucifixion (Erickson 213; Kroll 576; see John 19:25), "were by him all the while but not suffered to save him" from the executioner, "one Banister, a wild Irishman and one of the council, a fellow of absolute barbarity" (75-76). In this final scene, even the presence of women no longer has a tempering effect on male brutality-the women are impotent spectators. The complicit narrator is absent; the women who are present can merely watch in horror. As Pearson notes, female authority fails: "The maleness of those who betray and torture Oroonoko is remorselessly stressed... It is a 'Bold Englishman' and a 'wild Irishman'... who ultimately kill Oroonoko" (137). The male shadow is now so strongly projected that it overcomes the mitigating influence of anima projection.

The fact that much of the novel's violence takes place in the absence of women suggests not only an inappropriately bifurcated sense of gender but also a lack of integration and a projection of shadow and anima. The novel, however, deconstructs its own essentialist stance on male violence and female goodness in several ways. First, Imoinda is a warrior, a woman whose projected blind spots stand in the way of the shadow work that she herself needs to do. During the rebellion, she becomes a type of Amazon who shoots Byam in the shoulder, much as Oroonoko shoots the tiger through the eye. Imoinda thus manifests a version of Behn's male characters' violence against the Other-parallel actions that show the narrator's essentialism to be grounded in seventeenth-century European culture rather than in psychological reality. Second, the narrator may be complicit in the violence perpetrated by men, as Laura Brown acknowledges in observing "a perverse connection between the female narrator and Oroonoko's brutal executioners" (196). Third, there are male characters like Trefry who, though decent, support the institutional evils of slavery. In other words, while the novel does present examples of female benignity and extreme male violence, there is a middle ground where men are neither brutes nor saints, where the feminine principle (projected or not) has some impact, but where the ideology of slavery corrupts both sexes. Whether in real life or in Behn's fiction, humans' violence against other humans is not completely reducible to an iron-clad axiom; but her depiction of the projection process, which enables slavery and impels the novel toward tragedy, does provide a compensatory critique of slave culture. That is, the novel critiques slavery to the exact degree that the characters reinforce and uphold 


\section{Fike}

it through the presence of projection and the lack of individuation. In the final analysis, the absence of women provides an occasion for the nonintegrated shadow to manifest brutally against Oroonoko, a key to understanding the shadow's role in the disintegration of his psyche, and a fable of male brutality that is still relevant to the cultural situation in the present day.

\section{Works Cited}

Athey, Stephanie, and Daniel Cooper Alarcón. “Oroonoko's Gendered Economies of Honor/Horror: Reframing Colonial Discourse Studies in the Americas." Subjects\& Citizens: Nation, Race, and Gender from Oroonoko to Anita Hill. Ed. Michael Moon and Cathy N. Davidson. Durham: Duke UP, 1995. 27-55.

Behn, Aphra. Oroonoko, or the Royal Slave: A True History. 1688. Ed. Janet Todd. New York: Penguin, 2003.

Brown, Laura. "The Romance of Empire: Oroonoko and the Trade in Slaves.” Todd 180-208.

Chibka, Robert L. “'Oh! Do Not Fear a Woman's Invention': Truth, Falsehood, and Fiction in Aphra Behn's Oroonoko." Texas Studies in Literature and Language 30 (1988): 510-37.

Erickson, Robert A. "Mrs A. Behn and the Myth of Oroonoko-Imoinda." Eighteenth-Century Fiction 3 (1993): 201-16.

Ferguson, Moira. Subject to Others: British Women Writers and Colonial Slavery, 1670-1834. New York: Routledge, 1992.

Johnson, Robert A. We: Understanding the Psychology of Romantic Love. New York: Harper, 1983.

Jung, Carl G. The Collected Works of C. G. Jung. Ed. Sir Herbert Read et al. Trans. R. F. C. Hull. 20 vols. Bollingen Series 10. Princeton: Princeton UP, 1953-79.

Kroll, Richard. “Tales of Love and Gallantry.” Ariel 67 (2004): 573-604.

Miller, Eric. “Aphra Behn’s Tigers.” The Dalhousie Review 81.1 (2001): 47-65.

Pearson, Jacqueline. "Gender and Narrative in the Fiction of Aphra Behn.” Todd 111-42.

Rowland, Susan. C. G. Jung and Literary Theory. New York: Palgrave, 1999.

Jung: A Feminist Revision. Cambridge, UK: Polity, 2002.

Shakespeare, William. Othello. The Complete Works of Shakespeare. Ed. David Bevington. $4^{\text {th }}$ ed. New York: HarperCollins, 1992. 1117-66.

Spencer, Jane. “Aphra Behn's Oroonoko and Women's Literary Authority.” Early Women's Writers, 1600-1720. Ed. Anita Pacheco. London: Longman, 1998. 183-96. 
Sussman, Charlotte. "The Other Problem with Women: Reproduction and Slave Culture in Aphra Behn's Oroonoko." Rereading Aphra Behn: History, Theory, and Criticism. Ed. Heidi Hunter. Charlottesville: U of Virginia P, 1993. 212-33.

Todd, Janet. New Casebooks: Aphra Behn. London, Macmillan, 1999.

Von Der Vogelweide, Walter. "Virtue and Charm." Selected Poems of Walter Von Der Vogelweide, the Minnesinger. Trans. Walter Alison Phillips. London: Smith, Elder, 1896. 31-32. Digitalized 13 July 2006. 22 May 2008 <http://books.google.com/books>.

West, Rinda. Out of the Shadow: Ecopsychology, Story, and Encounters with the Land. Charlottesville: U of Virginia P, 2007. 